\title{
Impact of Different Manures on Ashwagandha (Withania somnifera Dunal.) Production under Rainfed Condition
}

\author{
Mayank Kumar $^{1 *}$, Kaushal Kumar ${ }^{1}$, Neeraj Kumar² and Arjun patel ${ }^{3}$ \\ ${ }^{1}$ Department of Soil and water conservation, Chandra Shekar Azad University of Agriculture and \\ Technology, Kanpur - 208 002, Uttar Pradesh, India \\ ${ }^{2}$ Department of Agronomy, Chandra Shekar Azad University of Agriculture and Technology, \\ Kanpur - 208 002, Uttar Pradesh, India \\ ${ }^{3}$ Department of Soil science, Narendra Deva University of Agriculture and Technology, \\ Faizabad - 224 229, Uttar Pradesh, India \\ *Corresponding author
}

\begin{tabular}{|c|c|}
\hline \multicolumn{2}{|r|}{ A B S T RA C T } \\
\hline & \multirow{6}{*}{ 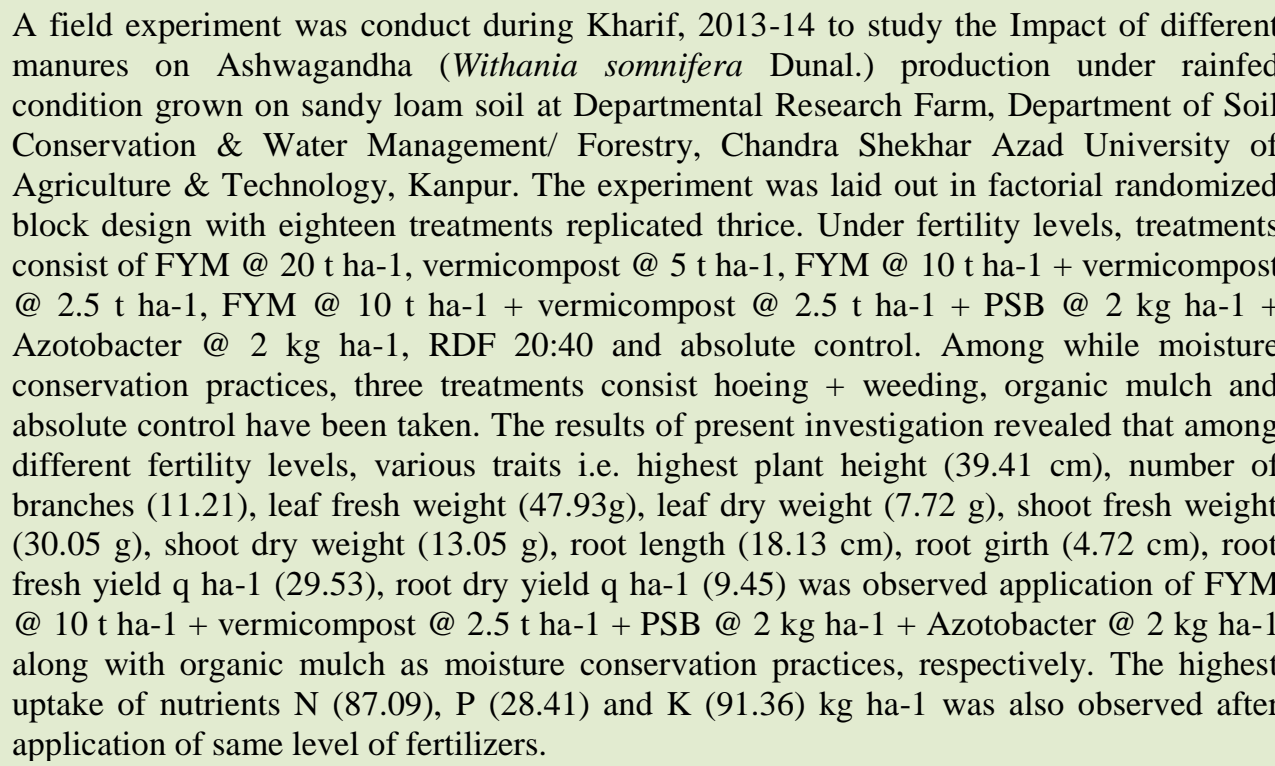 } \\
\hline & \\
\hline $\begin{array}{l}\text { Ashwagandha } \\
\text { (Withania } \\
\text { somnifera } \text { Dunal.), } \\
\text { Vermicompost, } \\
\text { Azotobacter }\end{array}$ & \\
\hline Article Info & \\
\hline $\begin{array}{l}\text { Accepted: } \\
\text { 28 August } 2017 \\
\text { Available Online: } \\
10 \text { October } 2017\end{array}$ & \\
\hline & \\
\hline
\end{tabular}

\section{Introduction}

Ashwagandha (Withania somnifera Dunal.) belong to the family (Solanaceae), known as "Indian ginseng" is a reputed medicinal herb grown for its roots in arid and semi-arid regions of many countries. Roots of this plant form ingredients of many herbal formulations prescribed for musculoskeletal conditions, nervous system and as a general health tonic for elderly persons and lactating mothers (Bone, 1996). It is an erect growing, branching shrub with a normal height of 1.50 $\mathrm{m}$. Ashwagandha is a dryland medicinal crop having tremendous marketing potential owing to demand of its roots to the tune of 7000 
tonnes and estimated production of 1500 tonnes (Umadevi et al., 2012). Ashwagandha root drug find an important place in Ayurveda for the treatment of rheumatic pain, inflammation of joints, nervous disorders, impotence and immature ageing and is considered as 'Indian ginseng' (Khanna et al., 2006; Kulkarni and Dhir, 2008).

Ashwagandha is a hardy and drought tolerant plant. It grows well in dry and subtropical regions. Madhya Pradesh, Gujarat, Haryana, Maharashtra, Punjab, Rajasthan and Uttar Pradesh are the main producing states of this crop in the country. In Madhya Pradesh alone it is cultivated in more than 5000 ha. The estimated production of its roots in India is more than $1500 \mathrm{t}$, while the annual requirement is about $7000 \mathrm{t}$ necessitating increase in its cultivation for higher production. Steroidal alkaloids and lactones in a class of constituents called with anolides are the major active principles of $W$. somnifera roots (Grigorescu et al., 1990). It cultivated over an area of 10,780 ha with a production of 8,429 tonnes in India. While the annual demand increase from 7,028 tonnes (2001-02) to 9,127 tonnes (2004-05) necessitating increase in its cultivation for higher production.

The application of inorganic nutrients may not significantly influenced the various economic traits in contradiction due to the fact that bio-synthesis of secondary metabolites is under genetic control to influence plant growth and seed yield in various responsive crops including Ashwagandha as reported by Umrao et al. (2008) but the development of a reliable and consistent inoculation technology deter mines that the application of Azospirillum, FYM and Vermicompost, inter action beneficial with regards to a biological model for fundamental studies on symbiotic associations between them to have a significant impact in future agricultural production. Therefore, the present experiment was conducted to see and evaluate a response of bio-organic nutrition through a application of FYM, Vermicompost and Azospirillum in Ashwagandha (Withania sominifera).

The application of an integrated plant nutrient supply system is becoming popular as it is scientifically sound and assures sustainable development in agriculture. The use of judicious combination of organic and inorganic fertilizer source is essential not only to maintain soil health but also sustain productivity (Malewar et al., 1998).

It is grown as rainfed crop in many parts of India under arid and semi-arid regions. It grows well in soils having residual moisture and single or two supplementary irrigations during the entire period of its growing season. Despite its drought tolerance capacity, prolonged soil moisture deficit inhibits the growth and development of the crop and adversely affects the crop yield potential and plant productivity.

Understanding the effect of long duration moisture stress on the active principle content and root quality will help to augment functional characterization and biochemical integration of molecular and genetic data. The objectives of this study were to understand the response of field grown $W$. somnifera to soil moisture deficit and the changes in root secondary metabolites productivity.

Low availability of soil moisture and high evapo-transpiration is considered one of the principal causes which decrease crop productivity worldwide. Soil moisture deficit perceived as drought stress results in drop in water potential in plants. As this condition develops, responses of a wide range of physiological and biochemical processes are induced. Some of these responses are directly 
triggered by the changing water status of the tissues while others are brought about by plant hormones that are signaling changes in water status (Chaves et al., 2003). In addition to the deleterious effects on primary metabolism and energy balance of the plant, water stress alters the secondary metabolism of plant and its sequestration in different parts (Harborne, 1999). The complex nature of plant secondary metabolism and diverse array of secondary metabolites demands the holistic approach to understand the combined biochemical, molecular, cellular, and physiological perspective to appreciate the true nature of the occurrence and their significance. Additionally, the importance of secondary metabolites is increasing rapidly as these compounds are utilized as raw materials for various industries and as therapeutic agents for animal and human health care (Coley and Barone, 1996; Nina and Lerdau, 2003). Understanding how soil moisture influence the growth conditions for higher productivity and maximal recovery of phytomedicines. Plant nutrient status or plant nutrition is one of the important factors which controls growth and development of the various characters and determines final yield potentiality. The pharmacological activity of the roots is attributed to the presence of several alkaloids and withaniols, which is affected due to nutritional status of the soil (Maheshwari et al., 2000). Limited efforts were made to study the performance of Ashwagandha at different doses of nutrition. It is obvious to find out a suitable dosage of nutrition as the nutrient levels tend to modify the microclimate which in turn influence metabolic activities of the plant, thereby growth and development.

Keeping the above point in view and fulfill the increasing demand of roots of this important crop, present investigation was carried out to study the "Impact of different manures and moisture conservation practices on Ashwagandha (Withania somnifera Dunal) Production under rainfed condition" with the following objectives includes, assess the impact of manures and fertilizers on growth and development of shoot and root of Ashwagandha. And to screen out the most suitable combination of organic manures for shoots and root growth of Ashwagandha. Also study the effect of moisture conservation practices on Ashwagandha. Finally analyze the economics of the various treatment.

\section{Materials and Methods}

\section{Location of the experiment}

The field experiment entitled "Impact of different manures and moisture conservation practices on Ashwagandha (Withania somnifera Duanal) Production under rainfed condition" was carried out from August 2013 to April 2014 at sandy loam soil at field No. A-4 of Herbal Research Farm, Department of Soil Conservation \& Water Management /Forestry, Chandra Sekhar Azad University of Agriculture \& Technology, Kanpur. The experiment site is situated at an altitute of $125.9 \mathrm{~m}$ above mean sea level with a geographical bearing of $25^{\circ} 28^{\prime}$ North latitute and $79^{\circ} 1$ ' East longitute.

\section{Soil}

The soil of experiment field constituting a part of Central Gangetic alluvium a $\mathrm{pH}$ is reported to be 7.49 , deep, sandy loam soil with kankar granules exposed to soil erosion. The topography is not gently sloping.

The water table in fairly deep. Before plantation of Ashwagandha crop, surface and subsurface of soil samples up to one meter depth were drawn randomly from different places and a composite representative sample was prepared for mechanical and chemical analysis. 
The data for initial soil characteristics of experimental site and method used and constituents analyzed are given in Table 3.2.

\section{Cropping history of the field}

The details about cropping of the experimental field (A-4) at soil conservation farm of C.S.A. University for the last five years are given in Table 3.3.

\section{Experimental details}

\section{Variety}

The variety selected for the present experiment was Poshita, which is developed by CIMAP, Lucknow and popularize under cultivayion in Northen India as well as in Uttar Pradesh because of its higher root yield and improved alkaloid content.

\section{Spacing}

A spacing $30 \mathrm{~cm}$ between the rows and $15 \mathrm{~cm}$ within the rows was adopted for all the treatments.

\section{Cultivation details}

\section{Sowing}

The seeds were sown in line with a spacing of $30 \mathrm{~cm}$ between rows on $27 \mathrm{Aug}, 2013$. The rows were thinned out at $30 \mathrm{DAS}$, so as to maintain an inter plant distance of $15 \mathrm{~cm}$.

\section{Manures and fertilizers}

All the organic manures, vermicompost, PSB (Phosphorus Solubilising Bacteria), Azotobacter, phosphatic fertilizers plus 50\% of nitrogenous fertilizers were applied as basal dose as per treatments. Remaining 50\% of nitrogenous fertilizers were applied as top dressing after 30 days of sowing away from plants along the row by opening a small furrow to a depth of $5 \mathrm{~cm}$ in bands and covered immediately. Nitrogen and phosphorus were applied in the form of urea, single super phosphate respectively.

\section{Harvesting}

The crop was harvested at 180 days after sowing when the roots attained maximum size. Light irrigation was given before harvesting for easy lifting up of roots. Harvesting was done manually by digging and uprooting the individual plants. The roots were separated and washed to remive the soil particles.

\section{Sampling procedure}

Five plants were selected at random from the net plot of each treatment and tagged for recording biometric observation such as plant height. For the estimation of number of branches, root development, fresh weight of root and shoot, dry weight of root and shoot sampling was done at 60, 90, 120, 150, days after sowing and at harvest. Five plants were utilized from each sampling plot leaving border rows.

\section{Observations}

The observations recorded and the methods followed during the course of investigation are furnished below.

\section{Plant height (cm)}

Plant height from base of the plant to the tip of the longest leaf was measured from 5 randomly tagged plants in each treatment at 60, 90, 120, 150 days after sowing (DAS) and at final harvest and their mean values were computed and presented.

\section{No. of branches per plant}

No. of branches was count from 5 randomly tagged plants in each treatment at 60, 90, 120, 
150 days after sowing (DAS) and at final harvest and their mean values were computed and presented.

\section{Fresh weight of shoots (g plant $\left.{ }^{-1}\right)$}

Five randomly selected plants from each plot were pulled out 60, 90, 120, 150 days after sowing (DAS) and at final harvest. After separation of leaves and roots, the shoots were weighed and there mean values were computed and expressed in grams per plants.

\section{Dry weight of shoots (g plant $\left.{ }^{-1}\right)$}

Five randomly selected plants from each plot were pulled out 60, 90, 120, 150 days after sowing (DAS) and at final harvest. After separation of leaves and root, the shoots were dried in hot air oven at $60^{\circ} \mathrm{C}$ temperature till the constant dry weights were obtained. There mean values were computed and expressed in grams per plants.

\section{Fresh weight of roots $\left(\mathrm{tha}^{-1}\right)$}

Five randomly selected plants from each plot were pulled out $60,90,120,150$ days after sowing (DAS) and at final harvest. After separation of leaves and roots, the roots were weighed and there mean values were computed and presented in $\mathrm{tha}^{-1}$.

\section{Dry weight of roots $\left(\mathrm{t} \mathrm{ha} \mathbf{~}^{-1}\right)$}

After recording the fresh weight, the roots were made in to small pices of 2 to 3 inches thick and shade-dried for 10 to 15 days until the constant weights were obtained. After uniform drying, the mean values of dry weight of roots were computed and expressed in $\mathrm{t} \mathrm{ha}^{-1}$.

\section{Plant analysis}

The plant samples collected and at final harvest for computing dry matter production were utilized for the purpose for analysis of nitrogen, phosphorus and potassium.

The leaves and shoot of the plant samples were dried at $60^{\circ} \mathrm{C}$ till constant weights were obtained and powdered with the help of Electronic Grinder.

The procedure for the analysis of nutrients are furnished below.

\section{Nitrogen (\%)}

The nitrogen content $(\%)$ in the dried plant samples was determined by Micro kjeldhal distillation method after digesting the organic matter by $\mathrm{H}_{2} \mathrm{O}_{2}$ (AOAC,1960) and expressed as percent nitrogen on dry weight basis.

\section{Phosphorus (\%)}

The plant samples were digested with a triacid mixture consisting of $\mathrm{HNO}_{3}: \mathrm{H}_{2} \mathrm{SO}_{4}: \mathrm{HCLO}_{4}$ $(9: 4: 1)$. The volume of digest was made up to $100 \mathrm{ml}$. Phosphorus content in triacid digest was determined by the development of yellow colour with Barton's reagent. The intensity of yellow colour was determined by using UV visible spectrophotometer at $640 \mathrm{~nm}$ (AOAC, 1960).

\section{Potassium (\%)}

The ' $\mathrm{K}$ ' content in triacid digest was determined by using ELICO Model 22 A Flame Photometer (AOAC, 1960).

\section{Uptake of nutrients}

The uptake of nutrients like $\mathrm{N}, \mathrm{P}$ and $\mathrm{K}$ at different stages was compiled using data on nutrients contents and dry matter yields.

Nutrient uptake $\left(\mathrm{kg} \mathrm{ha}^{-1}\right)=\frac{\% \text { Nutrient content } \mathrm{x} \text { Dry matter yield }\left(\mathrm{kg} \mathrm{ha}^{-1}\right)}{100}$ 


\section{Experimental Finding}

A field experiment carried out from August 2013 to April 2014 with sandy loam soil at field No. A-4 of Research Farm, Department of Soil Conservation \& Water Management /Forestry, Chandra Sekhar Azad University of Agriculture \& Technology, Kanpur to study the "Impact of different manures and moisture conservation practices on Ashwagandha (Withania somnifera Dunal.) Production under rainfed condition " The data recorded on various parameters were statistically analyzed and the results are presented here under various headings:

\section{Plant height (cm)}

The plant height of Ashwagandha was significantly influenced by fertility levels and moisture conservation practices at different stages of crop growth (Table 4.1 and Fig.3).

At 60, 90, 120, 150 DAS and harvest stage, the plant height significantly influenced by fertility levels and moisture conservation practices. The application of FYM @ $10 \mathrm{tha}^{-1}$ +vermicompost@2.5 tha ${ }^{-1}$ + PSB @ $2 \mathrm{~kg}$ $\mathrm{ha}^{-1}+$ Azotobacter @ 2 kg ha ${ }^{-1}$ recorded treatment of $\mathrm{F}_{5}$ the highest plant height (39.41 $\mathrm{cm})$ at harvest stage followed treatment of $\mathrm{F}_{4}$ application of FYM @ $10 \mathrm{t} \mathrm{ha}^{-1}+$ vermicompost@2.5 t ha ${ }^{-1}(38.10 \mathrm{~cm})$ while minimum plant height was recorded of treatment $F_{1}$ control $(30.06 \mathrm{~cm})$ under fertility levels. Among the moisture conservation practices the highest plant height was recorded treatment of $\mathrm{M}_{2}$ with hoeing and weeding $(36.63 \mathrm{~cm})$ followed treatment of $\mathrm{M}_{3}$ organic mulch $(35.38 \mathrm{~cm})$ while lowest plant height was recorded with treatment of $\mathrm{M}_{1}$ control $(34.92 \mathrm{~cm})$ at harvest stage.

\section{Number of Branches}

The number of branches plant $^{-1}$ in
Ashwagandha was significantly influenced by fertility levels and moisture conservation practices levels at different stages of crop growth (Table 4.2 and Fig.4).

At 60, 90, 120, 150 DAS and harvest stage, the number of branches plant ${ }^{-1}$ significantly influenced by fertility levels and moisture conservation practices. The application of FYM@10 tha $\mathrm{th}^{-1}$ + vermicompost @ $2.5 \mathrm{tha}^{-1}$ +PSB@ $2 \mathrm{~kg} \mathrm{ha}^{-1}+$ Azotobacter @ $2 \mathrm{~kg} \mathrm{ha}^{-1}$ recorded of treatment $\mathrm{F}_{4}$ the highest number of branches (11.21) at harvest stage followed by FYM @ $10 \mathrm{t} \mathrm{ha}^{-1}$ + vermicompost @ $2.5 \mathrm{t}$ ha $^{-1}$ of treatment $\mathrm{F}_{5}(10.81)$ while minimum number of branches was recorded with treatment $F_{1}$ (5.51) under control.

Among the moisture conservation practices the highest number of branches was recorded with treatment of $\mathrm{M}_{3}$ organic mulch (10.52) treatment $\mathrm{M}_{2}$ of hoeing and weeding (10.00) and lowest number of branches was recorded with treatment $\mathrm{M}_{1}$ of control (8.62) at harvest stage.

\section{Shoot fresh weight $\left(\mathrm{g} \mathrm{plant}^{-1}\right)$}

The shoot fresh weight of Ashwagandha was remarkably varied with fertility levels and moisture conservation practices at different stages of crop growth (Table 4.5 and Fig.7).

The shoot fresh weight significantly influenced by fertility levels and moisture conservation practices at the stages. While the shoot fresh weight registered a progressive increase from 60 to 120 DAS afterward there was a steep decrease in shoot fresh weight at harvest under different fertility levels.

Finally, the shoot fresh weight was significantly affected by fertility levels and moisture conservation practices. In $\mathrm{F}_{5}$ when we apply FYM @ $10 \mathrm{tha}^{-1}+$ vermicompost @ $2.5 \mathrm{tha}^{-1}+\mathrm{PSB} @ 2 \mathrm{~kg} \mathrm{ha}^{-1}+$ Azotobacter 
(a) $2 \mathrm{~kg} \mathrm{ha}^{-1}$ recorded the highest shoot fresh weight $(30.05 \mathrm{~g})$ at harvest stage followed by $\mathrm{F}_{4}$ of FYM @10 t ha ${ }^{-1}+$ vermicompost @ 2.5 $\mathrm{t} \mathrm{ha}^{-1}(24.13 \mathrm{~g})$ while minimum shoot fresh weight was recorded in $F_{1}$ of control (20.02 g).

In context to moisture conservation practices the highest shoot fresh weight was recorded in $\mathrm{M}_{3}$ with organic mulch (24.38 $\mathrm{g}$ ) followed by $\mathrm{M}_{2}$ of hoeing and weeding $(23.70 \mathrm{~g})$. The lowest shoot fresh weight was recorded in $\mathrm{M}_{1}$ of control (22.04 g) at harvest stage.

\section{Shoot dry weight (g plant $\left.{ }^{-1}\right)$}

The shoot dry weight of Ashwagandha was significantly influenced by different fertility levels and moisture conservation practices at different stages of crop growth (Table 4.6 and Fig.8). The shoot dry weight registered a progressive increase from 60 to 120 DAS thereafter drastically decrease in shoot dry weight at harvest under different fertility levels. In $\mathrm{F}_{5}$ treatment the application of FYM @ $10 \mathrm{t} \mathrm{ha}^{-1}+$ vermicompost @ $2.5 \mathrm{t} \mathrm{ha}^{-1}+$ PSB@2 kg ha ${ }^{-1}+$ Azotobacter@2 kg ha ${ }^{-1}$ recorded the highest shoot dry weight $(13.05$ g) at harvest stage followed treatment $\mathrm{F}_{4}$ in FYM@10 t ha ${ }^{-1}$ + vermicompost @ $2.5 \mathrm{t} \mathrm{ha}^{-1}$ $(9.50 \mathrm{~g})$ while minimum shoot dry weight was recorded in $F_{1}$ with control (8.26 g) among all fertility levels.

Among the moisture conservation practices the highest shoot dry weight was recorded in $\mathrm{M}_{3}$ treatment of organic mulch (10.18 g) followed by $\mathrm{M}_{2}$ of hoeing and weeding (9.84 g). The lowest shoot dry weight was recorded with treatment $\mathrm{M}_{1}$ of control $(9.27 \mathrm{~g})$ at harvest stage.

\section{Root yield (q ha ${ }^{-1}$ )}

Fresh root yield $\left(\mathbf{q} \mathbf{h a}^{-1}\right)$

The fresh root yield of Ashwagandha was significantly influenced by fertility levels and moisture conservation practices levels at different stages of crop growth (Table 4.9 and Fig.11).

The application of FYM @ $10 \mathrm{t} \mathrm{ha}^{-1}+$ vermicompost@2.5 tha ${ }^{-1}$ PSB @ $2 \mathrm{~kg} \mathrm{ha}^{-1}$ +Azotobacter@2 kg ha ${ }^{-1}$ recorded $\mathrm{F}_{5}$ the highest fresh root yield (29.53 q ha $\left.{ }^{-1}\right)$ at harvest stage followed by $\mathrm{F}_{4}$ application of FYM@10 tha ${ }^{-1}$ + vermicompost@ $2.5 \mathrm{t} \mathrm{ha}^{-1}$ $\left(22.28 \mathrm{q} \mathrm{ha}^{-1}\right)$ while minimum fresh root yield was recorded with $F_{1}$ of control $\left(9.66 \mathrm{q} \mathrm{ha}^{-1}\right)$ under fertility levels.

Among the moisture conservation practices the highest fresh root yield was recorded in $\mathrm{M}_{3}$ treatment of organic mulch (20.63 q ha ${ }^{-1}$ ) followed by $\mathrm{M}_{2}$ of hoeing and weeding (19.14 $\left.\mathrm{q} \mathrm{ha}{ }^{-1}\right)$. The lowest fresh root yield was recorded $\mathrm{M}_{1}$ of control (17.55 $\left.\mathrm{q} \mathrm{ha}^{-1}\right)$ at harvest stage. The mean fresh root yield was significantly differed under fertility levels and moisture conservation practices.

The maximum and significantly higher fresh root yield were obtained in association of application of FYM @ $10 \mathrm{t} \mathrm{ha}^{-1}+$ vermicompost@2.5 $\mathrm{t} \mathrm{ha}^{-1}$ + PSB @ $2 \mathrm{~kg} \mathrm{ha}^{-1}$ +Azotobacter@2 kg ha ${ }^{-1}$ along with organic mulch $\left(\mathrm{F}_{5} \mathrm{M}_{3}\right)$ (35.28 q ha $\left.{ }^{-1}\right)$ followed by application of FYM @ $10 \mathrm{t} \mathrm{ha}^{-1}+$ vermicompost@2.5 tha $\mathrm{th}^{-1}+\mathrm{PSB} @ 2 \mathrm{~kg} \mathrm{ha}^{-1}$ +Azotobacter@2 kg ha ${ }^{-1}$ along with hoeing and weeding $\left(\mathrm{F}_{5} \quad \mathrm{M}_{2}\right)\left(30.35 \mathrm{q} \mathrm{ha}{ }^{-1}\right)$ while minimum fresh root yield was recorded under over all control $\left(\mathrm{F}_{1} \mathrm{M}_{1}\right)\left(7.84 \mathrm{q} \mathrm{ha}^{-1}\right)$.

\section{Dry root yield (q ha $\left.{ }^{-1}\right)$}

The dry root yield of Ashwagandha was significantly differed by fertility levels and moisture conservation practices at different stages of crop growth (Table 4.9 and Fig.11). The application of FYM @ $10 \mathrm{t} \mathrm{ha}^{-1}+$ vermicompost@2.5 tha ${ }^{-1}$ + PSB @ $2 \mathrm{~kg} \mathrm{ha}^{-1}$ +Azotobacter@2 kg ha ${ }^{-1}$ recorded treatment 
of $\mathrm{F}_{5}$ the highest dry root yield $\left(9.45 \mathrm{q} \mathrm{ha}^{-1}\right)$ at harvest stage followed by treatment $\mathrm{F}_{4}$ application of FYM @ $10 \mathrm{t} \mathrm{ha}+$ vermicompost@ $2.5 \mathrm{t} \mathrm{ha}^{-1}\left(7.24 \mathrm{q} \mathrm{ha}^{-1}\right)$ while minimum dry root yield was recorded with $\mathrm{F}_{1}$ treatment control $\left(3.10 \mathrm{q} \mathrm{ha}^{-1}\right)$ under fertility levels.

Among the moisture conservation practices the highest dry root yield was recorded in $\mathrm{M}_{3}$ of organic mulch $\left(7.36 \mathrm{q} \mathrm{ha}^{-1}\right)$ followed by $\mathrm{M}_{2}$ of hoeing and weeding $\left(6.23 \mathrm{q} \mathrm{ha}^{-1}\right)$. The lowest dry root yield was recorded with $\mathrm{M}_{1}$ of control $\left(5.02 \mathrm{q} \mathrm{ha}^{-1}\right)$ at harvest stage.

Interaction effect of fertility levels and moisture conservation practices on dry weight of roots $\left(\mathrm{q} \mathrm{ha}^{-1}\right)$

The mean dry root yield $\left(\mathrm{q} \mathrm{ha}^{-1}\right)$ was significantly differences under fertility levels and moisture conservation practices. The maximum and significantly higher dry root yield were recorded under association of application of FYM @ $10 \mathrm{t} \mathrm{ha}^{-1}+$ vermicompost@2.5 tha ${ }^{-1}+$ PSB @ $2 \mathrm{~kg} \mathrm{ha}^{-1}$ +Azotobacter@2 kg ha ${ }^{-1}$ with organic mulch $\left(\mathrm{F}_{5} \mathrm{M}_{3}\right)\left(11.38 \mathrm{q} \mathrm{h}^{-1}\right)$ followed by application of FYM @ $10 \mathrm{t} \mathrm{ha}^{-1}$ + vermicompost @ $2.5 \mathrm{t}$ $\mathrm{ha}^{-1}+$ PSB @ $2 \mathrm{~kg} \mathrm{ha}^{-1}+$ Azotobacter @ $2 \mathrm{~kg}$ $\mathrm{ha}^{-1}$ along with hoeing and weeding $\left(\mathrm{F}_{5} \mathrm{M}_{2}\right)$ $\left(9.79 \mathrm{q} \mathrm{ha}^{-1}\right)$ however minimum dry root yield was obtained under over all control $\left(\mathrm{F}_{1} \mathrm{M}_{1}\right)$ $\left(2.53 \mathrm{qha}^{-1}\right)$.

\section{Nutrient uptake}

\section{Nitrogen uptake $\left(\mathrm{kg} \mathrm{ha}^{-1}\right)$}

It is evident from (Table 4.10 and Fig.12) that the nitrogen uptakeat harvest of the crop was significantly influenced by fertility levels and moisture conservation practices.

The highest nitrogen uptake at harvest was recorded by application of FYM @ $10 \mathrm{tha}^{-1}+$ vermicompost @ $2.5 \mathrm{tha}^{-1}+\mathrm{PSB} @ 2 \mathrm{~kg} \mathrm{ha}^{-1}$
+Azotobacter@2 kg ha-1 treatment of $\mathrm{F}_{5}$ $(87.09 \mathrm{~kg})$ followed by FYM @ $10 \mathrm{t} \mathrm{ha}^{-1}+$ vermicompost@2.5 t ha ${ }^{-1}$ treatment of $\mathrm{F}_{4}$ $(71.48 \mathrm{~kg})$ while lowest nitrogen uptake was recorded treatment of $F_{1}$ control $(33.18 \mathrm{~kg})$ under fertility levels.

At harvest, under moisture conservation practices, the highest nitrogen uptake was recorded by application of treatment of $\mathrm{M}_{3}$ organic mulch $\left(63.04 \mathrm{~kg} \mathrm{ha}^{-1}\right)$ followed by $\mathrm{M}_{2}$ of hoeing and weeding $\left(61.83 \mathrm{~kg} \mathrm{ha}^{-1}\right)$ and treatment $\mathrm{M}_{1}$ of control $\left(60.09 \mathrm{~kg} \mathrm{ha}^{-1}\right)$.

\section{Phosphorus uptake (kg ha $\left.{ }^{-1}\right)$}

It is evident from (Table 4.10 and Fig.12) that the Phosphorus uptake at harvest of the crop was significantly influenced by fertility levels and moisture conservation practices levels.

The highest Phosphorus uptakeat harvest was recorded by application of FYM @ $10 \mathrm{tha}^{-1}+$ vermicompost @ $2.5 \mathrm{tha}^{-1}+$ PSB @ $2 \mathrm{~kg} \mathrm{ha}^{-1}$ + Azotobacter @ $2 \mathrm{~kg} \mathrm{ha}^{-1}$ treatment of $\mathrm{F}_{5}$ $\left(28.41 \mathrm{~kg} \mathrm{ha}^{-1}\right)$ followed by FYM @ $10 \mathrm{tha}^{-1}$ + vermicompost @ $2.5 \mathrm{t} \mathrm{ha}^{-1}$ treatment of $\mathrm{F}_{4}$ $\left(23.26 \mathrm{~kg} \mathrm{ha}^{-1}\right)$ however lowest Phosphorus uptake was recorded treatment $\mathrm{F}_{1}$ of control $\left(8.65 \mathrm{~kg} \mathrm{ha}^{-1}\right)$ under fertility levels. At harvest, under moisture conservation practices, the highest Phosphorus uptake was recorded treatment of $\mathrm{M}_{3}$ application of organic mulch $\left(20.25 \mathrm{~kg} \mathrm{ha}^{-1}\right)$ followed by treatment $\mathrm{M}_{2}$ of hoeing and weeding (18.99 $\mathrm{kg} \mathrm{ha}^{-1}$ ) and control (M1) (17.32 $\left.\mathrm{kg} \mathrm{ha}^{-1}\right)$.

\section{Potassium uptake $\left(\mathrm{kg} \mathrm{ha}^{-1}\right)$}

It is clear from (Table 4.10 and Fig.12) that the potassium uptake at harvest of the crop was remarkably varied by fertility levels and moisture conservation practices. The highest potassium uptake at harvest was recorded treatment of $\mathrm{F}_{5}$ application of FYM @ $10 \mathrm{tha}$ 1 + vermicompost@ $2.5 \mathrm{t} \mathrm{ha}^{-1}$ + PSB @ $2 \mathrm{~kg}$ $\mathrm{ha}^{-1}+$ Azotobacter $@ 2 \mathrm{~kg} \mathrm{ha}^{-1}\left(91.36 \mathrm{~kg} \mathrm{ha}^{-1}\right)$ 
followed by treatment of $\mathrm{F}_{4}$ FYM @ $10 \mathrm{tha}^{-1}$ + vermicompost@ $2.5 \mathrm{t} \mathrm{ha}^{-1}\left(68.03 \mathrm{~kg} \mathrm{ha}^{-1}\right)$ however lowest potassium uptake was recorded treatment $\mathrm{F}_{1}$ of control $(22.70 \mathrm{~kg}$ ha ${ }^{1}$ ) under fertility levels.

Under moisture conservation practices, the highest potassium uptake was recorded in $\mathrm{M}_{3}$ by application of organic mulch $(59.07 \mathrm{~kg}$ $\mathrm{ha}^{-1}$ ) followed by $\mathrm{M}_{2}$ of hoeing and weeding $\left(57.35 \mathrm{~kg} \mathrm{ha}^{-1}\right)$ and $\mathrm{M}_{1}$ of control $(55.02 \mathrm{~kg}$ $\left.\mathrm{ha}^{-1}\right)$ at harvest.

\section{Economics}

The data pertaining to cost of cultivation, total income, net returns and benefit cost ratio are presented in (Table 4.12 and fig.14).

\section{Total Income (Rs. ha $\left.{ }^{-1}\right)$}

The highest total income (Rs.113400, ha ${ }^{-1}$ ) were obtained $\mathrm{F}_{5}$ with application of FYM @ $10 \mathrm{t} \mathrm{ha}^{-1}+$ vermicompost @ $2.5 \mathrm{t} \mathrm{ha}^{-1}+$ PSB @ $2 \mathrm{~kg} \mathrm{ha}^{-1}+$ Azotobacter @ $2 \mathrm{~kg} \mathrm{ha}^{-1}\left(\mathrm{~F}_{4}\right)$ followed by FYM @ $10 \mathrm{t} \mathrm{ha}^{-1}+$ vermicompost @ $2.5 \mathrm{tha}^{-1}\left(\mathrm{~F}_{3}\right)$ (Rs. $86880 \mathrm{ha}$ $\left.{ }^{1}\right)$ however, the total lowest income was recorded by control $\left(\mathrm{F}_{1}\right)$ (Rs 37,200 ha ${ }^{-1}$ ) under fertility levels. Under moisture conservation practices, highest income was obtained in $\mathrm{M}_{3}$ treatment with organic mulch (Rs. $88320 \mathrm{ha}^{-1}$ ) followed by $\mathrm{M}_{2}$ of hoeing and weeding (Rs.74760 ha ${ }^{-1}$ ) and lowest income was recorded with $\mathrm{M}_{1}$ of control (Rs.60240 ha ${ }^{-1}$ ).

\section{Net Returns (Rs. ha ${ }^{-1}$ )}

The highest net returns (Rs, $80611 \mathrm{ha}^{-1}$ ) were obtained with application of FYM @ $10 \mathrm{tha}^{-1}$ + vermicompost @2.5 tha ${ }^{-1}+$ PSB @ $2 \mathrm{~kg}$ $\mathrm{ha}^{-1}+$ Azotobacter@2 $\mathrm{kg} \mathrm{ha}^{-1}\left(\mathrm{~F}_{5}\right)$ followed $\mathrm{F}_{4}$ by FYM@10 t ha ${ }^{-1}$ + vermicompost @ $2.5 \mathrm{t} \mathrm{ha}^{-1}$ (Rs.54244 ha ${ }^{-1}$ ) while total lowest net returns was obtained in $F_{1}$ with control (Rs.15484 ha ${ }^{-1}$ ) among all fertility levels.
Under moisture conservation practices, highest net returns was obtained with $\mathrm{M}_{3}$ organic mulch (Rs.57083 $\mathrm{ha}^{-1}$ ) followed by $\mathrm{M}_{2}$ hoeing and weeding of (Rs.44843 ha ${ }^{-1}$ ) and lowest net returns was $M_{1}$ control obtained in (Rs.33363 ha ${ }^{-1}$ ).

\section{Benefit Cost Ratio}

Application of FYM @ $10 \mathrm{t} \mathrm{ha}^{-1}+$ vermicompost @ $2.5 \mathrm{t} \mathrm{ha}^{-1}+$ PSB @ $2 \mathrm{~kg} \mathrm{ha}^{-1}$ +Azotobacter@2 kg ha ${ }^{-1} \mathrm{~F}_{5}$ gave highest benefit cost ratio (2.45) followed by FYM @ $10 \mathrm{t} \mathrm{ha}^{-1}+$ vermicompost @ $2.5 \mathrm{t} \mathrm{ha}^{-1} \mathrm{~F}_{4}$ of (1.66) while lowest benefit cost ratio was received under $F_{1}$ of control (0.71) under fertility levels.

Among moisture conservation practices, highest benefit cost ratio was obtained with organic mulch $\mathrm{M}_{3}$ of (1.82) followed by $\mathrm{M}_{2}$ of hoeing and weeding (1.49) and lowest benefit cost ratio was received in control $\mathrm{M}_{1}$ of (1.24).

\section{Results and Discussion}

Since independence abundant inorganic fertilizers are used to achieve the maximum yield of agriculture crops in India. The continuous use of inorganic fertilizers deteriorates not only the soil health but environment also.

To cope up with the situation and to achieve the goal of sustainable agriculture it is mandatory to check the deterioration of the soil fertility by way of balancing the nutrient loss from the soil by making addition through organic and green manures and bio fertilizers that can help in maintaining optimum crop yield and long term sustainable productivity. The use of organic manures would be encouraged as they maintain the soil fertility, improve the physical condition of the soil and cover the risk of differences and deficiency of nutrients. 
Table.1 Initial soil characteristics of the experimental field before Ashwagandha sowing (August, 2013)

\begin{tabular}{|c|c|c|c|c|}
\hline S. No. & Constituents & Soil depth $(\mathrm{cm})$ & Values & Methods used \\
\hline \multicolumn{5}{|c|}{ 1. Mechanical Composition } \\
\hline 1.1 & Sand (\%) & $0-25$ & 55.3 & \multirow{3}{*}{$\begin{array}{l}\text { International Pipette Method } \\
\text { (Piper, 1966) }\end{array}$} \\
\hline 1.2 & Silt (\%) & $0-25$ & 22.4 & \\
\hline 1.3 & Clay (\%) & $0-25$ & 20.7 & \\
\hline \multicolumn{5}{|l|}{ 2. Physical properties } \\
\hline 2.1 & Bulk density $\left(\mathrm{Mg} \mathrm{m}^{-3}\right)$ & $\begin{array}{c}0-25 \\
1.43 \\
0-75 \\
75-100\end{array}$ & $\begin{array}{l}1.43 \\
1.52 \\
1.50 \\
1.55\end{array}$ & $\begin{array}{l}\text { Richards et al., (1954) (Hand } \\
\text { Book-60) }\end{array}$ \\
\hline 2.2 & Particle density $\left(\mathrm{Mg} \mathrm{m}^{-3}\right)$ & $0-25$ & 2.53 & \multirow{2}{*}{$\begin{array}{l}\text { USDA Handbook - } 60 \mathrm{~K} . \mathrm{R} . \\
\text { Box's Method }\end{array}$} \\
\hline 2.3 & Water holding capacity (\%) & $\begin{array}{c}0-25 \\
25-50 \\
50-75 \\
75-100\end{array}$ & $\begin{array}{l}31.16 \\
29.16 \\
28.44 \\
27.94\end{array}$ & \\
\hline 2.4 & Field capacity (\%) & $0-25$ & 18.56 & (Piper, 1966) \\
\hline 3. & Physico-chemical properties & & & \\
\hline 3.1 & Soil pH & $0-25$ & 7.49 & Beckman pH meter \\
\hline 3.2 & Electrical conductivity $\left(\mathrm{dSm}^{-1}\right)$ & $0-25$ & 0.35 & Phillips conductivity meter \\
\hline \multicolumn{5}{|l|}{ 4. Chemical properties } \\
\hline 4.1 & Organic carbon (\%) & $0-25$ & 0.34 & $\begin{array}{l}\text { Walkley and Black's rapid } \\
\text { titration method (Piper, 1966) }\end{array}$ \\
\hline 4.2 & Total nitrogen $(\%)$ & $.0-25$ & 0.037 & Kjeldahl method (Piper, 1966) \\
\hline 4.3 & Available Nitrogen $\left(\mathrm{kg} \mathrm{ha}^{-1}\right)$ & $0-25$ & 191 & $\begin{array}{l}\text { Alkaline per magnate method } \\
\text { (Subbiah \& Asija, 1956) }\end{array}$ \\
\hline 4.4 & Available Phosphorus $\left(\mathrm{kg} \mathrm{ha}^{-1}\right)$ & $0-25$ & 17.94 & Olsen's method (Olsen et al.,) \\
\hline 4.5 & Available Potash $\left(\mathrm{kg} \mathrm{ha}^{-1}\right)$ & $0-25$ & 164.95 & Muhr et al., (1963) \\
\hline
\end{tabular}

Table. 2 Cropping history of the experimental field

\begin{tabular}{|c|c|c|c|}
\hline S.No. & Years & Kharif & Rabi \\
\hline 1. & $2008-09$ & Safed Musli & Japanese Mint \\
\hline 2. & $2009-10$ & French Bsil & Japanese Mint \\
\hline 3. & $2010-11$ & Kalmegh & Isabgol \\
\hline 4. & $2011-12$ & Kalmegh & Isabgol \\
\hline 6. & $2012-13$ & Ashwagandha & Ashwagandha \\
\hline 7. & $2013-14$ & Ashwagandha & Ashwagandha \\
\hline
\end{tabular}

The details of the treatments are furnished below

\begin{tabular}{|l|l|l|}
\hline $\mathrm{F}_{1} \mathrm{M}_{1}$ & $:$ & Absolute control (No manures, biofertilizers and inorganic fertilizers) \\
\hline $\mathrm{F}_{1} \mathrm{M}_{2}$ & $:$ & Hoeing + Weeding \\
\hline
\end{tabular}




\begin{tabular}{|c|c|c|}
\hline $\mathrm{F}_{1} \mathrm{M}_{3}$ & $:$ & Organic mulch \\
\hline $\mathrm{F}_{2} \mathrm{M}_{1}$ & $:$ & FYM @ $20 \mathrm{tha}^{-1}$ \\
\hline $\mathrm{F}_{2} \mathrm{M}_{2}$ & $:$ & FYM @ $20 \mathrm{t} \mathrm{ha}^{-1}+$ Hoeing + Weeding \\
\hline $\mathrm{F}_{2} \mathrm{M}_{3}$ & $:$ & FYM @ $20 \mathrm{t} \mathrm{ha}^{-1}+$ Organic mulch \\
\hline $\mathrm{F}_{3} \mathrm{M}_{1}$ & : & Vermicomposting@ @ $\mathrm{t} \mathrm{ha}^{-1}$ \\
\hline $\mathrm{F}_{3} \mathrm{M}_{2}$ & $:$ & Vermicomposting @ 5 tha ${ }^{-1}+$ Hoeing + Weeding \\
\hline $\mathrm{F}_{3} \mathrm{M}_{3}$ & : & Vermicomposting@ @ 5 tha $^{-1}+$ Organic mulch \\
\hline $\mathrm{F}_{4} \mathrm{M}_{1}$ & $:$ & FYM @ 10 tha ${ }^{-1}+$ Vermicomposting @ $2.5 \mathrm{t} \mathrm{ha}^{-1}$ \\
\hline $\mathrm{F}_{4} \mathrm{M}_{2}$ & : & FYM @ $10 \mathrm{tha}^{-1}+$ Vermicomposting @ $2.5 \mathrm{tha}^{-1}+$ Hoeing + Weeding \\
\hline $\mathrm{F}_{4} \mathrm{M}_{3}$ & : & FYM @ $10 \mathrm{tha}^{-1}+$ Vermicomposting @ $2.5 \mathrm{t} \mathrm{ha}^{-1}+$ Organic mulch \\
\hline $\mathrm{F}_{5} \mathrm{M}_{1}$ & $:$ & $\begin{array}{l}\text { FYM @ } 10 \mathrm{tha}^{-1}+\text { Vermicomposting @ } 2.5 \mathrm{t} \mathrm{ha}^{-1}+\operatorname{PSB}\left(2 \mathrm{~kg} \mathrm{ha}^{-1}\right)+\text { Azotobacter } \\
\left(2 \mathrm{~kg} \mathrm{ha}^{-1}\right)\end{array}$ \\
\hline $\mathrm{F}_{5} \mathrm{M}_{2}$ & $:$ & $\begin{array}{l}\text { FYM @ } 10 \mathrm{tha}^{-1}+\text { Vermicomposting @ } 2.5 \mathrm{t} \mathrm{ha}^{-1}+\text { PSB }\left(2 \mathrm{~kg} \mathrm{ha}^{-1}\right)+\text { Azotobacter } \\
\left(2 \mathrm{~kg} \mathrm{ha}^{-1}\right)+\text { Hoeing + Weeding }\end{array}$ \\
\hline $\mathrm{F}_{5} \mathrm{M}_{3}$ & $:$ & $\begin{array}{l}\text { FYM @ } 10 \mathrm{t} \mathrm{ha}^{-1}+\text { Vermicomposting @ } 2.5 \mathrm{t} \mathrm{ha}^{-1}+\text { PSB }\left(2 \mathrm{~kg} \mathrm{ha}^{-1}\right)+\text { Azotobacter } \\
\left(2 \mathrm{~kg} \mathrm{ha}^{-1}\right)+\text { Organic mulch }\end{array}$ \\
\hline $\mathrm{F}_{6} \mathrm{M}_{1}$ & : & Recommended dose of fertilizers N and P @ 20:40 kg ha ${ }^{-1}$ \\
\hline $\mathrm{F}_{6} \mathrm{M}_{2}$ & $:$ & Recommended dose of fertilizers N and P @ 20:40 $\mathrm{kg} \mathrm{ha}^{-1}+$ Hoeing + Weeding \\
\hline $\mathrm{F}_{6} \mathrm{M} 3$ & : & Recommended dose of fertilizers N and P @ 20:40 kg ha ${ }^{-1}+$ Organic mulch \\
\hline
\end{tabular}

Interaction effect of fertility levels and moisture conservation practices on fresh weight of roots $\left(\mathbf{q ~ h a}{ }^{-1}\right)$

\begin{tabular}{|c|c|c|c|c|}
\hline \multirow{2}{*}{ Fertility levels } & \multicolumn{3}{|c|}{ Moisture conservation practices } & \multirow{2}{*}{ Mean } \\
\cline { 2 - 4 } & $\mathbf{M}_{\mathbf{1}}$ & $\mathbf{M}_{\mathbf{2}}$ & $\mathbf{M}_{\mathbf{3}}$ & \\
\hline $\mathrm{F}_{1}$ & 7.80 & 9.42 & 11.75 & $\mathbf{9 . 6 5}$ \\
$\mathrm{F}_{2}$ & 15.40 & 18.60 & 22.05 & $\mathbf{1 8 . 6 8}$ \\
\hline $\mathrm{F}_{3}$ & 18.00 & 21.25 & 24.65 & $\mathbf{2 1 . 3 0}$ \\
$\mathrm{F}_{4}$ & 18.40 & 23.50 & 26.15 & $\mathbf{2 2 . 6 8}$ \\
\hline $\mathrm{F}_{5}$ & 22.15 & 30.60 & 35.70 & $\mathbf{2 9 . 4 8}$ \\
\hline $\mathrm{F}_{6}$ & 11.00 & 13.80 & 17.90 & $\mathbf{1 4 . 2 3}$ \\
\hline Mean & $\mathbf{1 5 . 4 5}$ & $\mathbf{1 9 . 5 2}$ & $\mathbf{2 3 . 0 3}$ & \\
\hline S.E $\pm(\mathbf{D})$ & $\mathbf{0 . 3 0}$ & \multicolumn{3}{|}{} \\
\hline C.D(P=0.05) & $\mathbf{0 . 6 1}$ & \multicolumn{3}{l}{} \\
\hline
\end{tabular}


Interaction Effect - Effect of fertility levels and moisture conservation practices on dry weight of roots $\left(\mathrm{q} \mathrm{ha}^{-1}\right)$

\begin{tabular}{|c|c|c|c|c|}
\hline \multirow[t]{2}{*}{ Fertility levels } & \multicolumn{3}{|c|}{ Moisture conservation practices } & \multirow[t]{2}{*}{ Mean } \\
\hline & M1 & M2 & M3 & \\
\hline F1 & 2.53 & 3.03 & 3.75 & 3.10 \\
\hline $\mathrm{F} 2$ & 5.00 & 5.98 & 7.08 & 6.02 \\
\hline F3 & 5.85 & 6.77 & 7.87 & 6.83 \\
\hline $\mathrm{F} 4$ & 5.97 & 7.42 & 8.33 & 7.24 \\
\hline F5 & 7.18 & 9.79 & 11.38 & 9.45 \\
\hline F6 & 3.57 & 4.41 & 5.73 & 4.57 \\
\hline Mean & 5.02 & 6.23 & 7.36 & \\
\hline S.E $\pm(D)$ & 0.431 & & & \\
\hline C.D $(P=0.05)$ & 0.875 & & & \\
\hline
\end{tabular}

Keeping the above facts in view, the present investigation was conduct to study the "Impact of different manures on Ashwagandha (Withania somnifera Dunal.) production under rainfed condition "to promote the use of organic inputs for better yield and quality produce in response poor area. The result obtained from the experiment are discussed here under.

Effect of organic manures, inorganic fertilizers and biofertilizers on growth attributes

Plant growth is a dynamic process and is affected by the complex interaction between environmental factors and physiological process. Besides these factors, nutrition and moisture plays a very important role. In the present experiment, application of organic manures and biofertilizers exerted significant influences on growth characters such as plant height, number of branches, fresh and dry leaf weight, fresh and dry shoot weight over inorganic fertilizers.

At maturity, the plant height range from 30.06 $\mathrm{cm}$ to $39.41 \mathrm{~cm}$. The plant height was found to increase with the age of the crop period from 60 DAS till the harvest. A steady increase in plant height was observed between
60-90 DAS $(3.79 \mathrm{~cm})$ while a maximum increase in plant height was observed between 90 to 120 DAS $(11.39 \mathrm{~cm})$. Further the plant heights gradually increase from 120-150 DAS $(8.64 \mathrm{~cm})$ while the marginal increase in plant height was observed between 150 DAS up to the harvest $(0.76 \mathrm{~cm})$, irrespective of the treatments. The highest plant height recorded in $\mathrm{F}_{5}$ treatment by application of FYM @ $10 \mathrm{t}$ $\mathrm{ha}^{-1}+$ vermicompost@2.5t ha ${ }^{-1}+$ PSB @ 2 kg ha ${ }^{-1}+$ Azotobacter@ 2 kg ha ${ }^{-1}$ (39.41 cm) followed by $\mathrm{F}_{4}$ of i.e. application of FYM @ $10 \mathrm{t} \mathrm{ha}^{-1}$ + vermicompost @ 2.5t ha ${ }^{-1}$ (38.10 $\mathrm{cm}$ ) while minimum plant height was recorded with treatment of $F_{1}$ of control $(30.06 \mathrm{~cm})$ among the fertility levels due to readily availability of $\mathrm{N}$ and other fertilizers. This might have resulted in increase in ABA content and minimal production of Auxin and cytokinin essential for plant growth. Krauss (1978) reported that under condition of reduced nitrogen availability. ABA content increase in both roots and shoots in potato.

At harvest, the number of branchesplant ${ }^{-1}$ ranged from 5.51 to 11.21 among different treatments. The highest number of branches plant $^{-1}$ recorded with the treatment of $F_{4}$ with application FYM @ $10 \mathrm{t}^{-1} \mathrm{ha}^{-1}+$ Vermicomposting@2.5 t ha ${ }^{-1}(11.21)$ and minimum number of branches was recorded 
with treatment of $F_{1}$ of control (5.51) under fertility levels.

Goel and Duhan (2011) reported the similar trends after application of FYM @ 12.5 and $25 \mathrm{t} /$ ha increases the average number of primary branches significantly from 2.0 to 2.3 and 2.6 over control.

The shoot fresh and dry weight increase from 60 to 120 DAS and thereafter decrease until harvest. At harvest, the highest shoot fresh and dry weight was recorded in treatment of $\mathrm{F}_{5}$ with application of FYM @ $10 \mathrm{t} \mathrm{ha}^{-1}+$ vermicompost @ 2.5t ha ${ }^{-1}+$ PSB @ $2 \mathrm{~kg} \mathrm{ha}^{-1}$ +Azotobacter@ $2 \mathrm{~kg} \mathrm{ha}^{-1}$ (30.05 g and 13.05 $\mathrm{g}$, respectively.) while the lowest shoot fresh and dry weight was recorded in treatment of $\mathrm{F}_{1}$ control (20.02 $\mathrm{g}$ and $8.26 \mathrm{~g}$, respectively.) under fertility levels.

Meshran and Shender (1990) confirmed the response of Azotobacter on height of shoot and total yield of dry shoots $(40.47 \mathrm{~cm}$ and $145 \mathrm{~g}$ per plot, respectively) over control (31.8 $\mathrm{cm}$ and 103.25 per plot, respectively).

Effect of organic manures, inorganic fertilizers and biofertilizers on yield attributes and yield

The root characters like root yield and dry root yield were significantly influenced by fertility levels and moisture conservation practices. At harvest, the fresh root yield range from $9.66 \mathrm{q} \mathrm{ha}^{-1}$ to $29.53 \mathrm{q} \mathrm{ha}^{-1}$. The highest fresh root yield were recorded in treatment of $\mathrm{F}_{5}$ by application of FYM @ $10 \mathrm{t}$ $\mathrm{ha}^{-1}+$ vermicompost @ 2.5t ha ${ }^{-1}+$ PSB @ 2 $\mathrm{kg} \mathrm{ha}^{-1}+$ Azotobacter@ $2 \mathrm{~kg} \mathrm{ha}^{-1}$ (29.53 q ha $\left.{ }^{1}\right)$ while the lowest fresh root yield was recorded in treatment of $F_{1}$ control (9.66 q ha ${ }^{1}$ ) under fertilizer levels.

Finally, the dry root yield range from $3.10 \mathrm{q}$ ha ${ }^{-1}$ to $9.45 \mathrm{q} \mathrm{ha}^{-1}$. The highest dry root yield were recorded in treatment of $\mathrm{F}_{5}$ by application of FYM @10 $\quad \mathrm{t}^{-1}+$ vermicompost@2.5t ha ${ }^{-1}+$ PSB @ $2 \mathrm{~kg} \mathrm{ha}^{-1}$ +Azotobacter@2 kg ha ${ }^{-1}\left(9.45 \mathrm{q} \mathrm{ha}^{-1}\right)$ while the lowest dry root yield was recorded in treatment of $F_{1}$ control $\left(3.10 \mathrm{q} \mathrm{ha}^{-1}\right)$ under fertility levels.

\section{Nutrient uptake $\left(\mathrm{kg} \mathrm{ha}^{-1}\right)$}

\section{Nitrogen $\left(\mathrm{kg} \mathrm{ha}^{-1}\right)$}

At harvest, the nitrogen uptake was range from 33.18 to $87.09 \mathrm{~kg} \mathrm{ha}^{-1}$. The highest nitrogen uptake at harvest was recorded in treatment of $\mathrm{F}_{5}$ with application of FYM @ $10 \mathrm{t} \mathrm{ha}^{-1}+$ vermicompost @ 2.5t ha ${ }^{-1}+$ PSB @ $2 \mathrm{~kg} \mathrm{ha}^{-1}+$ Azotobacter@ $2 \mathrm{~kg} \mathrm{ha}^{-1}(87.09$ $\mathrm{kg} \mathrm{ha}{ }^{-1}$ ) while minimum nitrogen uptake recorded in treatment of $F_{1}$ with control $\left(33.18 \mathrm{~kg} \mathrm{ha}^{-1}\right)$ under fertility levels.

\section{Phosphorus (kg ha $\left.{ }^{-1}\right)$}

At harvest, the phosphorus uptake was range from 8.65 to $28.41 \mathrm{~kg} \mathrm{ha}^{-1}$. The highest phosphorus uptake at harvest was recorded in treatment of $\mathrm{F}_{5}$ with application of FYM @ $10 \mathrm{t} \mathrm{ha}^{-1}+$ vermicompost @ 2.5t ha $\mathrm{h}^{-1}+\mathrm{PSB}$ @ $2 \mathrm{~kg} \mathrm{ha}^{-1}+$ Azotobacter @ $2 \mathrm{~kg} \mathrm{ha}^{-1}(28.41$ $\mathrm{kg} \mathrm{ha}^{-1}$ ) while minimum phosphorus uptake recorded in treatment of $F_{1}$ with control (8.65 $\mathrm{kg} \mathrm{ha}^{-1}$ ) under fertility levels.

Prakash Rao et al., (1985) also confirm the results as increase nitrogen application up to $100 \mathrm{~kg} \mathrm{ha}^{-1}$ with the phosphorus uptake in lemon grass.

\section{Potassium (kg ha $\left.{ }^{-1}\right)$}

At harvest, the potassium uptake was range from 22.70 to $91.36 \mathrm{~kg} \mathrm{ha}^{-1}$. The highest potassium uptake at harvest was recorded in treatment of $\mathrm{F}_{5}$ with application of FYM @ $10 \mathrm{t} \mathrm{ha}^{-1}+$ vermicompost @ 2.5t ha ${ }^{-1}+$ PSB 
@ $2 \mathrm{~kg} \mathrm{ha}^{-1}+$ Azotobacter @ $2 \mathrm{~kg} \mathrm{ha}^{-1}(91.36$ $\mathrm{kg} \mathrm{ha}^{-1}$ ) while minimum potassium uptake recorded in treatment of $\mathrm{F}_{1}$ with control $\left(22.70 \mathrm{~kg} \mathrm{ha}^{-1}\right)$ under all fertility levels.

Under moisture conservation practices, the potassium uptake ranged from 55.02 to 59.07 $\mathrm{kg} \mathrm{ha}{ }^{-1}$. The highest potassium uptake was recorded in treatment of $\mathrm{M}_{3}$ with organic mulch $\left(59.07 \mathrm{~kg} \mathrm{ha}^{-1}\right)$ and lowest potassium uptake was recorded in treatment of $\mathrm{M}_{1}$ with control $\left(55.02 \mathrm{~kg} \mathrm{ha}^{-1}\right)$.

Prakash Rao et al., (1985) also reported that increase nitrogen application up to $100 \mathrm{~kg} \mathrm{ha}^{-1}$ increased the potassium uptake in lemon grass.

\section{Economics}

The net returns were obtained highest in treatment of $\mathrm{F}_{5}$ with application of FYM @ $10 \mathrm{tha}^{-1}+$ vermicompost @ 2.5t ha $\mathrm{h}^{-1}+$ PSB @2 $\mathrm{kg} \mathrm{ha}^{-1}+$ Azotobacter @ $2 \mathrm{~kg} \mathrm{ha}^{-1}$ (Rs.80611) while lowest net returns were recorded in treatment of $F_{1}$ control (Rs. 15484) and highest Benefit Cost Ratio were recorded in treatment of $\mathrm{F}_{5}$ with application of FYM@ $10 \mathrm{tha}^{-1}+$ vermicompost @ $2.5 \mathrm{tha}^{-1}$ +PSB@ $2 \mathrm{~kg} \mathrm{ha}^{-1}+$ Azotobacter @ $2 \mathrm{~kg} \mathrm{ha}$ ${ }^{1}(2.45)$ while lowest Benefit Cost Ratio were recorded in treatment of $F_{1}$ control $(0.71)$ under fertility levels.

Ashwagandha (Withania somnifera Dunal.) belongs to the family Solanaceae and is one of the most potential medicinal crops of the future. Ashwagandha is grown primarily for its roots which contain number of alkaloids including Withanine and Somniferine having medicinal properties along with a reducing sugar phytosterol, ipuranal and mixture of saturated and unsaturated fatty acids which are present in different parts of the plants. The root is a tonic, stimulant, alliterative, aphrodisiac, narcotic, diuretic and abortifacient. Powdered leaf suspensions can increase total serum protein synthesis by two fold.

The field experiment entitled "Impact of different manures on Ashwagandha (Withania somnifera Dunal.) production under rainfed condition "was carried out from August 2013 to April 2014 at sandy loam soil at field No. A-4 of Research Farm, Department of Soil Conservation \& Water Management /Forestry, Chandra Sekhar Azad University of Agriculture \& Technology, Kanpur.

The experiment was laid out in Randomized block design (RBD) with three replications. The results of the present investigation are summarized below.

At harvest, the application of FYM @ $10 \mathrm{t}$ ha 1 + vermicompost @ $2.5 \mathrm{t} \mathrm{ha}^{-1}+$ PSB @ $2 \mathrm{~kg}$ $\mathrm{ha}^{-1}+$ Azotobacter @ $2 \mathrm{~kg} \mathrm{ha}^{-1}$ of treatment $\mathrm{F}_{5}$ $(39.41 \mathrm{~cm})$ recorded the highest plant height and lowest plant height was recorded with treatment of $F_{1}$ control $(30.06 \mathrm{~cm})$ under fertility levels.

Under moisture conservation practices, the highest plant height was recorded with treatment of $\mathrm{M}_{2}$ hoeing and weeding (36.63 $\mathrm{cm})$ and lowest plant height was recorded under treatment of $\mathrm{M}_{1}$ control $(34.92 \mathrm{~cm})$.

The number of branches plant ${ }^{-1}$ was highest with application of FYM @ $10 \mathrm{t} \mathrm{ha}^{-1}+$ vermicompost@2.5 tha ${ }^{-1}+$ PSB @ $2 \mathrm{~kg} \mathrm{ha}^{-1}$ + Azotobacter@2 kg ha ${ }^{-1}$ of treatment $\mathrm{F}_{4}$ (11.21) and lowest number of branches were recorded in treatment $F_{1}$ of control (5.51) under fertility levels while in case of moisture conservation practices, highest number of branches was recorded with treatment $\mathrm{M}_{3}$ consisting organic mulch (10.52) and lowest were recorded in treatment $\mathrm{M}_{1}$ of control (8.62) at maturity stage. 
The highest shoot fresh and dry weight $g$ plant $^{-1}$ was recorded with application of FYM @10 t ha ${ }^{-1}+$ vermicompost @ $2.5 \mathrm{t} \mathrm{ha}^{-1}+$ PSB@2 $\mathrm{kg} \mathrm{ha}^{-1}+$ Azotobacter @ $2 \mathrm{~kg} \mathrm{ha}^{-1}$ of treatment $\mathrm{F}_{5}$ (30.05 and $\left.13.05 \mathrm{~g} \mathrm{plant}^{-1}\right)$, respectively. The lowest shoot fresh and dry weight $\mathrm{g}_{\text {plant }}{ }^{-1}$ was recorded with treatment $\mathrm{F}_{1}$ of control (20.02 and $\left.8.26 \mathrm{~g} \mathrm{plant}^{-1}\right)$, respectively under fertility levels at maturity. Under moisture conservation practices, highest shoot fresh and dry weight $\mathrm{g}$ plant ${ }^{-1}$ was recorded with treatments $\mathrm{M}_{3}$ organic mulch $\left(24.38\right.$ and $10.18 \mathrm{~g}$ plant $\left.^{-1}\right)$ respectively, the lowest shoot fresh and dry weight was recorded with treatment of $\mathrm{M}_{1}$ control $\left(22.04\right.$ and $9.27 \mathrm{~g}$ plant $\left.^{-1}\right)$, respectively.

At maturity, the highest fresh and dry root yield $\mathrm{q} \mathrm{ha}^{-1}$ was recorded with application of FYM@ $10 \mathrm{tha}^{-1}+$ vermicompost @ $2.5 \mathrm{tha}^{-1}$ +PSB@2 kg ha ${ }^{-1}+$ Azotobacter @ $2 \mathrm{~kg} \mathrm{ha}^{-1}$ of treatment $\mathrm{F}_{5}\left(29.53 \mathrm{q} \mathrm{ha}^{-1}\right.$ and $\left.9.45 \mathrm{q} \mathrm{ha}^{-1}\right)$ followed by treatment $\mathrm{F}_{4}$ of FYM @ $20 \mathrm{t} \mathrm{ha}^{-1}$ + vermicompost @5 t ha ${ }^{-1}$, respectively. However, the lowest fresh and dry root yield $\mathrm{q} \mathrm{ha}^{-1}$ was recorded with treatment $\mathrm{F}_{1}$ of control (9.66 q ha ${ }^{-1}$ and $3.10 \mathrm{q} \mathrm{ha}^{-1}$ ), respectively under all fertility levels.

Under moisture conservation practices, the maximum fresh and dry root yield $\mathrm{q} \mathrm{ha}^{-1}$ was recorded with treatments $\mathrm{M}_{3}$ of organic mulch (20.63 and $7.36 \mathrm{q} \mathrm{ha}^{-1}$ ), respectively, while the minimum fresh and dry root yield was recorded with treatment $\mathrm{M}_{1}$ of control (17.55 and $5.02 \mathrm{q} \mathrm{ha}^{-1}$ ), respectively.

The highest $\mathrm{N}, \mathrm{P}$ and $\mathrm{K}$ uptake $\mathrm{kg} \mathrm{ha}^{-1}$ was recorded with application of FYM @ $10 \mathrm{tha}^{-1}$ + vermicompost@2.5 t ha ${ }^{-1}$ + PSB @ $2 \mathrm{~kg}$ $\mathrm{ha}^{-1}+$ Azotobacter $@ 2 \mathrm{~kg} \mathrm{ha}^{-1}$ of treatment $\mathrm{F}_{5}$ $\left(87.09,28.41\right.$ and $\left.91.36 \mathrm{~kg} \mathrm{ha}^{-1}\right)$ respectively. The lowest N, P and K uptake was recorded with treatment of $F_{1}$ control $(33.18,8.65$ and $22.70 \mathrm{~kg} \mathrm{ha}^{-1}$ ) respectively under fertility level at the time of harvesting of ashwagandha crop. Under moisture conservation practices, the maximum $\mathrm{N}, \mathrm{P}$ and $\mathrm{K}$ uptake was observed in treatment $\mathrm{M}_{3}$ of organic mulch $(63.04,20.25$ and $59.07 \mathrm{~kg}$ $\mathrm{ha}^{-1}$ ), respectively. The minimum N, P and K uptake was recorded with treatment $\mathrm{M}_{1}$ of control (60.09, 17.32 and $55.02 \mathrm{~kg} \mathrm{ha}^{-1}$ ), respectively.

Among all fertility levels, the highest total water used by application of FYM @ $10 \mathrm{t} \mathrm{ha}^{-1}$ +vermicompost@2.5 t ha ${ }^{-1}$ + PSB@2 kg $\mathrm{ha}^{-1}+$ Azotobacter $2 \mathrm{~kg} \mathrm{ha}^{-1}$ treatment in $\mathrm{F}_{5}$ of (316.1 mm) followed by treatment of $\mathrm{F}_{4} \mathrm{FYM}$ @ $10 \mathrm{t} \mathrm{ha}^{-1}+$ vermicompost @ $2.5 \mathrm{t} \mathrm{ha}^{-1}$ $(310.9 \mathrm{~mm})$ and lowest total water used in treatment $F_{1}$ of control $(304.4 \mathrm{~mm})$. In case of moisture conservation practices, the highest water use in treatment $\mathrm{M}_{3}$ of organic mulch (314.2 $\mathrm{mm}$ ) followed by treatment $\mathrm{M}_{2}$ of hoeing and weeding $(312.1 \mathrm{~mm})$ while lowest total water used in treatment $\mathrm{M}_{1}$ of control (310.6 mm), In context to moisture conservation practices.

\section{Economics}

The highest Net Returns was recorded with application of FYM @ $10 \mathrm{t} \mathrm{ha}^{-1}+$ vermicompost@2.5 tha ${ }^{-1}+$ PSB @ $2 \mathrm{~kg} \mathrm{ha}^{-1}$ + Azotobacter@2 kg ha ${ }^{-1}$ of treatment $\mathrm{F}_{5}$ (Rs. 80611) and lowest net returns was recorded with treatment $F_{1}$ of control (Rs. 15484) under fertility levels. Under moisture conservation practices, the highest net returns was recorded with treatment $\mathrm{M}_{3}$ of organic mulch (Rs. 57083) and lowest net returns was recorded with treatment $\mathrm{M}_{1}$ of control (Rs. 33363).

The experimental results revealed that application of FYM @ $10 \mathrm{t} \mathrm{ha}^{-1}+$ vermicompost@2.5 tha $\mathrm{ha}^{-1}+\mathrm{PSB} @ 2 \mathrm{~kg} \mathrm{ha}^{-1}$ + Azotobacter@2 kg ha-1 of treatment $\mathrm{F}_{5}$ recorded highest root yield and gave more 
Total Income, Net Returns and B: C Ratio while lowest Total Income, Net Returns and B: C Ratio were recorded with treatment of $F_{1}$ control under fertility level.

\section{References}

Aishwath, O. P. (2004).Mineral nutrition and growth of Withania somnifera. J. Trop. Medicinal Plants 5 (1) 111-118.

Boudh, G.K and Pandey, R.(2013). Influence of organic and inorganic source of nutrients on growth, yield and quality of ashwagandha Information Center, Hisar, India, Crop Research (Hisar)46, (1/3), 226-230.

Chalapathi. M.V., Shivaraj, B. and Parama, V.R.R. (1997). Nutrient uptake and yield of steva (Stevia rebaudiana Bertoni) as influenced by methods of planting and fertilizer levels, Crop Research, Hisar 14(2): 205-208.

Gajbhiya, R.P. and Deshmukh, S.B.(2010). Root production and seed yield of ashwagandha as influenced by organic manures and biofertilizers Central Institute of Medicinal and Aromatic Plant Science, 32(4) 358-361.

Gajbhiye, R.P. and Deshmukh, S.B. (2010). Root production and seed yield of ashwagandha as influenced by organic manures and biofertilizers. J. Medicinal and Aromatic Plant Sci; 32:4, 358-361.

Gopal H, Natrajan, T. and Raja, P.(2006), Effect of rhizobacterial inoculation on rhizospheremicroflora of Ashwaganadha cv Jahahar 20. International J. Agric. Sci., 2(2): 392-395.

Grigorescu E, Elsakka M, Stanescu U, (1990). New data referring to chemistry of Withania somnifera species. Rev. Med. Chir. Soc. Med. Nat. Iasi. 94:385-387.

Gupta, A. K., Upadhyay, and Pachauri, S. P. (2000). Ashwagandha: A boon from nature for human and animals. Indian farmers' Digest 13-14.

Khana P K, Kumar A, Ahuja A, Kishen Kaulm (2006). Biochemical composition of roots of Withania somnifera (L.) Dunal. Asian J. Plant Sci. 5: 1061-1063.

Krauss, (1978).Tuberization and abscisic acid content in Solanum tuberosum as affected by nitrogen nutrition. Potato Research 21: 183-193.

Kubsad, V.S., Palled, Y.B. and Mansur, C.P., (2009), Productivity quality and economics of rainfed Ashwgandha (Withania somnifera) as influenced by spacing and fertiliaer levels. Indian $J$. Agron., 54(4): 449-453.

Kulkarni, S. and Dhir, A. (2008). Withania somnifera an Indian ginseng progress Neuro- Phychopharmacool. Biol. Psychiatry 32 (5) 1093-1105.

Kumar, N., Kumar, V. and Singh, M.C. (2012).Response of bio organic nutrition on growth yield and quality of Ashwagandha (Withania somnifera). Hort. Flora Research Spectrum. 1:(3), 208-214.

Lakshmanan, A., Govindarajan, K. and Kumar, K.,(2005).Effect of seed treatment with native diazotrophs on the seedling parameters of Senna and Ashwagandha. Crop Res., 30(1): 119-123.

Maheshwari, S.K. and Yadav, S.(1981).Response of Withania soniferato variable levels of $\mathrm{N}$ and $\mathrm{p}$ rainfed. Paper presented at the IV All India Workshop on Medicinal and Aromatic Plants, Madhuri $31^{\text {st }}$ August - September 3, pp: 11-12.

Maheshwari, S.K., Sharma, R.K. and Gangrade, S.K., (2000).Response of Ashwagandha (Withania somnifera) to organic manures and fertilizers in a shallow black soil under rainfed condition. Indian J. Agron., 45(1): 214-216.

Maitra, S., Jana, B.K. and Debnath, S.(1998).Response of plant nutrients on growth and alkaloid content of Aswagandha (Withania somunifera). J. Intera cademicia 2(4): 243-246.

Mathumanickum, D. and Balakrishnamurthy, G. (1999).Studies on nutritional requirement of ashwagandha (Withania somnifera Dunal), in Shevroy hills of Tamil Nadu, 
India. J. Spice \& Arom. Crops, 8(2): 179183.

Meena K. and Upadhyay, G.(2012).Effect of spacing organic manures and time of transplanting on growth and yield of ashwagandha MKK Publication, Kolkata, India Environment and Ecology 30, (4), 1272-1275.

Meshran and Shender (1990).Effect of nitrogen, phosphorus and biofertilizers (Azotobacter) on yield and uptake in onion. J.Agric. 81 (5): 277-279.

Nigam, K.B., Rawat G.S. and Prasad, B.(1984).Effect of methods of sowing plant density and fertility level on ashwagandha (Withania somnifera Dunal). South Indian Hort., 32(6) 356359.

Pakkiyanathan, K., Pasha, Y.N., Narayan Reddy, Y. and Sathe, A.(2004). Effect of spacing and phosphorus levels on growth and root yield of Ashwgandha (Withania somnifera Dunal). Indian J. Hort., 61(2): 195-197.

Panchabhai, D.M., Bachkar, B.R., Ghawade,S.M. and Wankhade S.G.(2005). Effect of nitrogen and phosphorus on growth and seed yield of Ashwgandha (Withania somnifera Dunal.) The Orissa J. Hort., 33(1): 11-15. Pandey, S.T., Singh, P. and Pandey, P. (2006).Site specific nutrient management for Withania somnifera at subtropical belt of Uttaranchal.Intern. J. Agril. Sci., 2(2): 626-628.

Prakash Rao,G.V.S., Munna Singh and Ganesh Rao, R.S. (1985). Effect of N, P and K fertilizers on the yield and nutrient uptake in lemon grass (Cymbopogan martini Stapf. var. Motia). International $J$. Tropical Agric. 3(2): 123-127.

Ramesh, P., Reddy, K.S; Ramana, S; Maji and Ajay(2005)Effect of nitrogen and farm yard manure on physiological parameters in ashwagandha vertisol soil type. Indian Journal of Plant Physiology, 10, 4, 389393.

Singh, S.P. and Mishra, H.O. (1997).Production technology of ashwagandha. Training manual skill-cum-technology upgradation programme on improved technologies for production of Medicinal and Aromatic Plant.CIMAP: 52-55.

Skribic, K.(1987).The effect of nitrogen nutrition on quality in some carrot cultivars. Agrohenija No. 4: 263-273.

Toyohara, H., Kikuno, H., Irie, K. and Kikuchi, F. (1997). Effect of mulching on growth of yam (Dioscoreaalata L.) varieties introduced from tropical region. Japanese J. of Tropical Agric.; 41:2, 74-80.

Umadevi M, Rajeswari R, Sharmila Rahale C, Selvavenkadesh S, Pushpa R, Sampath Kumar K P, Bhowmik D (2012). Traditional and medicinal uses Withania somnifera. Pharma innov. 1(9) : 102-110.

VisalGoel, Duhan, B.S (2013). Agri- BioPublishers, Hisar, India, Annals of Biology, 29, (2) : 171-174.

Vishal Goel Duhan, Madan, B.S, Dev Raj and Ramprakash, V.K. (2011). Effect of nitrogen and FYM on yield growth parameters and quality of Ashwagandha (Withania somnifera). Annals of Agri. Bio Research; 16:(2),101-106.

\section{How to cite this article:}

Mayank Kumar, Kaushal Kumar, Neeraj Kumar and Arjun patel. 2017. Impact of Different Manures on Ashwagandha (Withania somnifera Dunal.) Production under Rainfed Condition. Int.J.Curr.Microbiol.App.Sci. 6(10): 5043-5059. doi: https://doi.org/10.20546/ijcmas.2017.610.479 